\title{
Targeting LKB1 in cancer - exposing and exploiting vulnerabilities
}

\author{
M Momcilovic ${ }^{1}$ and D B Shackelford ${ }^{\star}, 1$ \\ ${ }^{1}$ Department of Pulmonary and Critical Care Medicine, David Geffen School of Medicine, University of California, Los Angeles, \\ CA 90095, USA
}

The LKB1 tumour suppressor is a serine/threonine kinase that functions as master regulator of cell growth, metabolism, survival and polarity. LKB1 is frequently mutated in human cancers and research spanning the last two decades have begun decoding the cellular pathways deregulated following LKB1 inactivation. This work has led to the identification of vulnerabilities present in LKB1deficient tumour cells. Pre-clinical studies have now identified therapeutic strategies targeting this subset of tumours that promise to benefit this large patient population harbouring LKB1 mutations. Here, we review the current efforts that are underway to translate pre-clinical discovery of therapeutic strategies targeting LKB1 mutant cancers into clinical practice.

Liver kinase B1 (LKB1, also known as STK11) was first identified as the causal mutation in Peutz-Jeghers Syndrome (PJS), a rare inherited autosomal dominant disorder characterised by the development of benign gastrointestinal hamartomas and the early onset of cancer (Hemminki et al, 1998). However, more than a decade later, LKB1 has become recognised as a critical tumoursuppressor gene that is frequently mutated in a broad spectrum of human cancers. LKB1 is a serine threonine kinase that directly phosphorylates and regulates the adenosine monophosphateactivated protein kinase (AMPK) and 12 other AMPK-like kinases to regulate a broad spectrum of cellular functions including: growth, metabolism, autophagy and polarity (Figure 1) (Shackelford and Shaw, 2009). The past decade has witnessed an intense effort to understand the molecular mechanisms that underlie basic cellular deregulation that occurs following LKB1 inactivation in cancer. Unlike targeting gain-of-function mutations with targeted inhibitors such as the drug Imatinib that inhibits the $\mathrm{BCR}-\mathrm{ABL}$ tyrosine kinase driver mutation in chronic myeloid leukaemia (Druker et al, 2001), loss-of-function mutations in tumour suppressors present a unique therapeutic challenge. Owing to the lack of a clear target, a synthetic lethal approach is required to identify liabilities in growth and survival pathways in order to expose weak points in LKB1 mutant tumours that may be therapeutically exploited. Additionally, a clear understanding of the deregulation of key pathways downstream of LKB1 and its substrates will likely hold the key to developing effective therapies for the treatment of LKB1 mutant cancers. Here, we review the current strategies and research efforts to develop personalised treatments targeting tumours bearing LKB1 mutations.

\section{STRATIFYING PATIENTS BY LKB1 LOSS OF FUNCTION}

The predisposition of PJS patients to early-onset tumours predicted that LKB1 inactivation is an important event in carcinogenesis (Hemminki, 1999). Subsequent genetic analysis of tumours has demonstrated that LKB1 is frequently inactivated in human tumours of the cervix, ovaries, skin, pancreas and, recently, the kidneys (Sanchez-Cespedes, 2007). LKB1-inactivating mutations are common in non-small cell lung cancer patients (NSCLC) through loss of heterozygosity on chromosome 19p that frequently accompanies nonsense and missense mutations as well as deletions (Fernandez et al, 2004). Non-small cell lung cancer patients is a heterogeneous disease comprising tumours of varying histopathological subtypes. LKB1 mutations were detected in approximately $20-30 \%$ of lung adenocarcinoma (ADC), $70 \%$ of mucinous bronchiolar $\mathrm{ADC}$ and to a lesser extent in squamous and large cell carcinomas (Sanchez-Cespedes et al, 2002; Ji et al, 2007; Osoegawa et al, 2011; Wilkerson et al, 2012). Moreover, The Cancer Genome Atlas (TCGA) project confirmed these studies and identified LKB1 as the third most frequently mutated gene in human lung ADC (Ding et al, 2008). Therefore, it reasons that in order to successfully treat LKB1 mutant cancers, patient biopsies must first be routinely screened for LKB1 inactivation.

*Correspondence: Dr DB Shackelford; E-mail: DShackelford@mednet.ucla.edu

Received 13 March 2015; revised 2 June 2015; accepted 7 June 2015; published online 21 July 2015

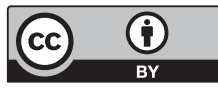




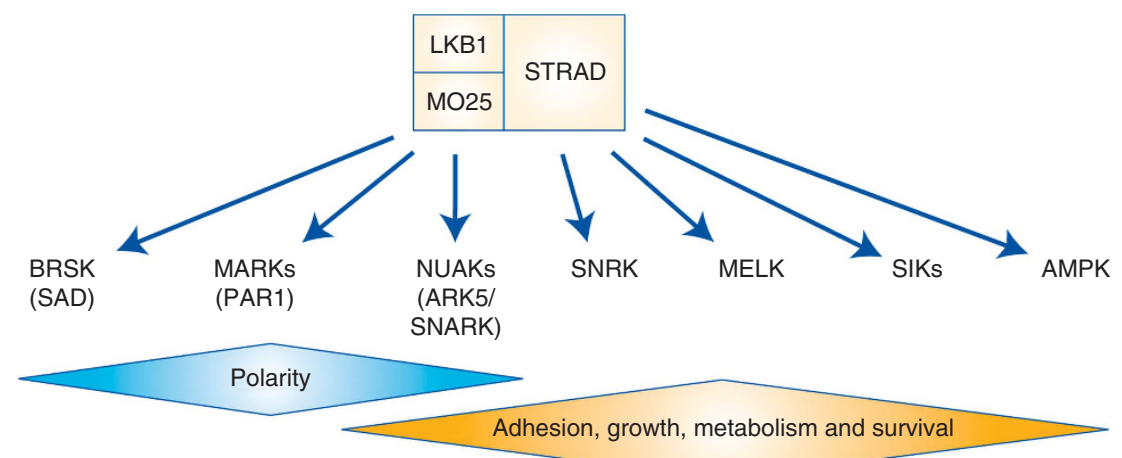

Figure 1. LKB1 regulates an AMPK-like family of kinase. LKB1 in complex with STRAD and MO25 phosphorylates AMPK and AMPK-like kinases to regulate polarity, adhesion, growth, metabolism and cell survival.

It will be critical to implement standardised genetic and molecular screening of LKB1 inactivation for patients. However, routine screening for LKB1 gene mutations is not standard-of-care practice making it difficult to stratify patients by LKB1 inactivation. Accurate detection of LKB1 mutations require a combination of deep sequencing techniques including Sanger sequencing to detect point mutations and loss of heterozygosity as well as exon sequencing by Multiplex ligation-dependent probe amplification (Ji et al, 2007; Wingo et al, 2009). Immunohistochemical staining of total LKB1 protein on formalin-fixed paraffin-embedded biopsies may provide an effective alternative approach to costly sequencing as a means to identify the loss of LKB1 in cancer. Tumours were stratified by LKB1 loss in two biomarker studies examining LKB1 expression in NSCLC and head and neck squamous cell carcinoma (Kline et al, 2011; Nakada et al, 2013). However, immunohistochemical staining of total LKB1 protein does not distinguish between functional and non-functional LKB1. Additional staining of lung tumour biopsies for phosphorylated AMPK at threonine 172 (P-AMPKthr172) did show a significant and positive correlation between low LKB1 expression and low P-AMPKthr172 levels in lung tumours demonstrating the utility of using both LKB1 and P-AMPKthr172 as clinical biomarkers (Nakada et al, 2013). Examination of transcript levels of LKB1 may prove to be a more feasible and cost-effective method compared with multiple deep sequencing techniques. A recent study examining gene expression profiles in NSCLC identified a unique profile for LKB1 mutant lung tumours as compared with tumours expressing functional LKB1. Interestingly, the authors identified a large population of lung tumours with no detectable genetic mutations in LKB1 but exhibiting a LKB1 mutant gene expression profile. Examination of LKB1 transcript levels showed that these genetically wild-type but functionally mutant tumours had reduced LKB1 transcript levels confirming that the inactivation of LKB1 may occur at the genetic and transcriptional level (Kaufman et al, 2014). Additionally, in melanoma cells with BRAF V600E mutation, LKB1 can be inactivated by phosphorylation by ERK and Rsk leading to reduced AMPK phosphorylation levels (Zheng et al, 2009). The combination of deep sequencing, transcript and protein analysis combined would ensure the detection of LKB1 inactivation in tumours, however, this may not be the most practical route for clinical application. Therefore, functional assays that directly measure the LKB1 activation following treatment with AMPK activators such as AICAR or phenformin could in theory be performed on tumour biopsies cultured ex vivo (Shaw et al, 2004b; Hawley et al, 2010). This type of assay would require culturing and/or preserving tumour biopsies ex vivo and could serve as a simple and routine screening method to detect LKB1 deficiencies. Thus, multiplexing various assays is likely to prove the most effective approach to identify LKB1 inactivation in a broad spectrum of human tumours.
TARGETING VULNERABILITIES IN LKB1-DEFICIENT TUMOURS

Exploiting energetic stress. LKB1 was discovered to be the key upstream activator of the AMPK, thus, identifying LKB1 as a regulator of cell metabolism (Hawley et al, 2003; Hong et al, 2003; Woods et al, 2003; Shaw et al, 2004b). Adenosine monophosphateactivated protein kinase functions as a central metabolic regulator found in all eukaryotes that governs glucose and lipid metabolism and autophagy in response to alterations in nutrients and intracellular energy levels. Adenosine monophosphate-activated protein kinase is the only LKB1 substrate that is activated under low ATP conditions following nutrient deprivation or hypoxia and functions as a cellular rheostat maintaining energy homeostasis. Adenosine monophosphate-activated protein kinase is activated as well by CaMKK $\beta$ in response to calcium flux (Hawley et al, 2005; Hurley et al, 2005; Woods et al, 2005). Adenosine monophosphateactivated protein kinase exists as a heterotrimeric complex composed of a catalytic subunit (AMPK $\alpha 1, \alpha 2)$ and two regulatory subunits (AMPK $\beta 1, \beta 2$ and AMPK $\gamma 1, \gamma 2, \gamma 3$ ). Adenosine monophosphate-activated protein kinase is activated upon the direct binding of ADP or AMP to a $\gamma$ subunit where AMPK undergoes a conformational change leading to the phosphorylation of Thr172 on the activation loop of the $\alpha$ subunits (Hardie et al, 2011; Oakhill et al, 2011; Xiao et al, 2011). Upon cellular energy stress, AMPK activates catabolic pathways with the concomitant inhibition of anabolic metabolism, which serve to restore energy homeostasis (Mihaylova and Shaw, 2011; Hardie et al, 2012).

Tumour cells lacking LKB1 are hypersensitive to apoptosis in culture following treatment with energy stress-inducing agents, presumably originating from an inability to restore ATP levels owing to AMPK deficiency (Shaw et al, 2004b). Thus, selective killing of LKB1-deficient tumour cells can be achieved by mimicking energy stress with small molecule AMPK agonists such as the AMP mimetic AICAR or the biguanide metformin and phenformin, which are both inhibitors of mitochondrial complex I (Dykens et al, 2008) (Table 1). LKB1 loss selectively sensitises human cell lines and genetically engineered mouse models (GEMMs) of NSCLC as well as mouse MC38 colon cancer and Lewis lung carcinoma cell lines by inducing energetic stress and metabolic catastrophe that resulted in cellular apoptosis (Algire et al, 2011; Shackelford et al, 2013b) (Figure 2). Adenosine monophosphate-activated protein kinase was recently shown to be degraded by the cancer-specific MAGE-A3/6-TRIM28 ubiquitinase in cancer cells leading to its downregulation and hypersensitivity to AMPK agonists AICAR and metformin (Pineda et al, 2015). Screening for reduced AMPK protein expression may be a clinically viable means to predict metabolic hypersensitivity in 
Table 1. Drugs that can be used to target LKB1-deficient tumours

\begin{tabular}{|c|c|c|c|}
\hline Drug(s) & Target(s) & Vulnerability & Reference \\
\hline Metformin, Phenformin & Complex I of ETC & Energetic stress & $\begin{array}{l}\text { Shaw et al, 2004b; Algire et al, 2011; } \\
\text { Shackelford et al, 2013a }\end{array}$ \\
\hline Bafilomycin A, saliphenylhalamide A & Lysosomal acidification & $\begin{array}{l}\text { Compromised autophagy, } \\
\text { mitochondrial metabolism }\end{array}$ & Guo et al, 2011; Kim et al, 2013 \\
\hline Rapamycin & mTORC1 & $\begin{array}{l}\text { Dependence on high } \\
\text { mTOR kinase activity }\end{array}$ & $\begin{array}{l}\text { Wei et al, 2008; Shackelford et al, 2009a; } \\
\text { Contreras et al, 2010; Liang et al, 2010; } \\
\text { Shorning et al, 2011; Tanwar et al, 2012; } \\
\text { Damsky et al, } 2015\end{array}$ \\
\hline AZD8055 & mTOR catalytic kinase, dual PI3K & Dependence on high & Carretero et al, 2010; Andrade-Vieira et al, 2014; \\
\hline BEZ235 & and mTOR kinase & mTOR kinase activity & Cheng et al, 2014 \\
\hline AZD6224/BEZ235/Dasatinib & MEK, PI3K/mTOR and SRC & $\begin{array}{l}\text { Combinatorial targeting of } \\
\text { signalling pathways }\end{array}$ & $\begin{array}{l}\text { Carretero et al, 2010; Chen et al, 2012; } \\
\text { Liu et al, 2012b }\end{array}$ \\
\hline Sunitib & $\begin{array}{l}\text { Multi-target receptor tyrosine } \\
\text { kinases }\end{array}$ & Inhibition of angiogenesis & Gandhi et al, 2009 \\
\hline Tunicamycin, brefeldin A, 2-deoxyglucose & $\begin{array}{l}\text { ER, glycolysis, unfolded protein } \\
\text { response }\end{array}$ & $\begin{array}{l}\text { ER stress activation, } \\
\text { metabolic stress }\end{array}$ & Inge et al, 2014 \\
\hline BAPN & Lysyl oxidase & $\mathrm{ECM}$ & Gao et al, 2010 \\
\hline
\end{tabular}

Abbreviations: $\mathrm{ECM}=$ extracellular matrix; $E R=$ endoplasmic reticulum; $E T C=$ electron transport chain. Drugs along with their known targets are grouped based on LKB1-dependent vulnerability that is exploited by each class of drugs.

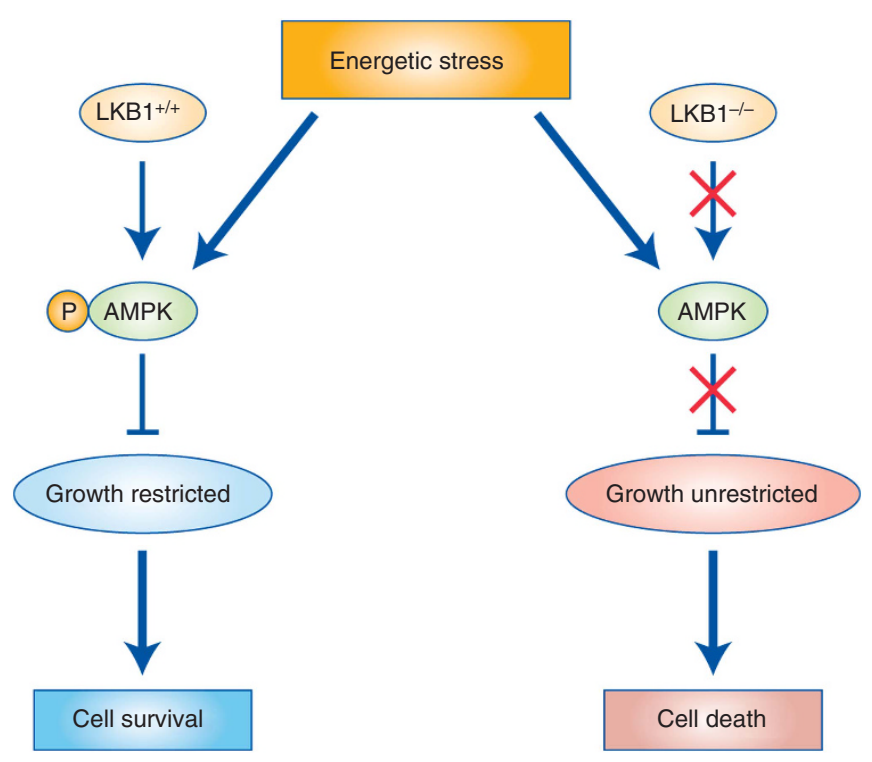

Figure 2. LKB1-deficient cells show select sensitivity to energetic stress. In the presence of energetic stress, LKB1-competent cells activate AMPK, which results in growth restriction and cell survival. LKB1-deficient cells in the presence of energetic stress fail to activate AMPK and thus continue with unrestricted growth leading to metabolic catastrophe and cell death.

tumours. Metformin, (known as Glucophage clinically) is the most widely used type 2 diabetes drug in the world and is taken daily by approximately 120 million patients worldwide. Several retrospective studies revealed a strong correlation between reduced cancer risk and mortality in diabetic patients taking metformin (Evans et al, 2005; Bowker et al, 2006; Pollak, 2010; Currie et al, 2012), agreeing with early studies showing that biguanides suppressed naturally arising tumours in both transgenic and carcinogen-treated rodent cancer models (Schneider et al, 2001; Anisimov et al, 2005).

In order to inhibit complex I of ETC, metformin but not phenformin requires the cell membrane-bound organic cation transporter 1 (OCT1) for intracellular transport (Gorboulev et al, 1997; Segal et al, 2011). OCT1 is mainly expressed in the liver, while expression levels in human cancers are variable (Hayer-Zillgen et al, 2002). Phenformin, which is the more potent of the two biguanides, was banned in the United States in the late 1970s by the FDA owing to the rare but fatal lactic acidosis (Crofford, 1995; Owen et al, 2000). Phenformin-induced lactic acidosis occurs in $0.002 \%$ of patients in which $50 \%$ of those cases were fatal (Fimognari et al, 2006). Importantly, when compared with toxicities associated with front-line chemotherapies, and targeted chemotherapies such as EGRF tyrosine kinase inhibitors, where incidence of fatal adverse events is reported at $2 \%$ for patients receiving chemotherapy or EGFR tyrosine kinase inhibitor therapy, risk of phenformin-induced lactic acidosis might be outweighed by potential benefits offered by the drug (Qi et al, 2013). Of interest, toxicity to biguanides is associated with poor renal function and clearance of the drugs; however, this is routinely screened for in cancer patients as those with compromised renal function are excluded from severely toxic chemotherapies (Janus et al, 2010; Lalau, 2010; Ohara et al, 2012). The toxicity profiles of biguanides and potentially other metabolic therapies must be evaluated in the correct context if these drugs are to be repurposed as anti-cancer therapies. In addition to identifying the correct dosing of biguanides in cancer, it will also need to be determined in what clinical context metabolic therapies will be utilised - be it cancer prevention, neoadjuvant or adjuvant therapy, or treatment of late stage non-resectable tumours. The success of metabolic therapies in the clinic will likely be predicated on rigorous preclinical studies in rodent models of cancer that examine physiologically achievable concentrations of these drugs and identify their appropriate clinical application in oncology (Dowling et al, 2012).

Deregulation of ULK1-mediated autophagy and mitophagy. Recent work in haematopoietic stem cells and NSCLC has shed light on the role of LKB1 as a regulator of mitochondrial homeostasis and autophagy. Deletion of $l k b 1$ in murine haematopoietic stem cells revealed mitochondrial defects including increased mitochondrial content and reduced mitochondrial membrane function (Gan et al, 2010; Gurumurthy et al, 2010; Nakada et al, 2010). Of interest, these studies implicate LKB1 as a regulator of stem cells. However, more studies are needed to understand how LKB1 regulates stem cells and how LKB1 inactivation deregulates cancer-initiating cells. It was then discovered that AMPK directly phosphorylates the Unc51-like kinases 1 and 2 (ULK1/2), key early regulators of autophagy and mitophagy (Egan et al, 2011) (Figure 3). Ampk ${ }^{-1-}$ and Ulk $1^{-1-}$ murine embryonic fibroblasts displayed defects in autophagy and displayed the accumulation of aberrant 


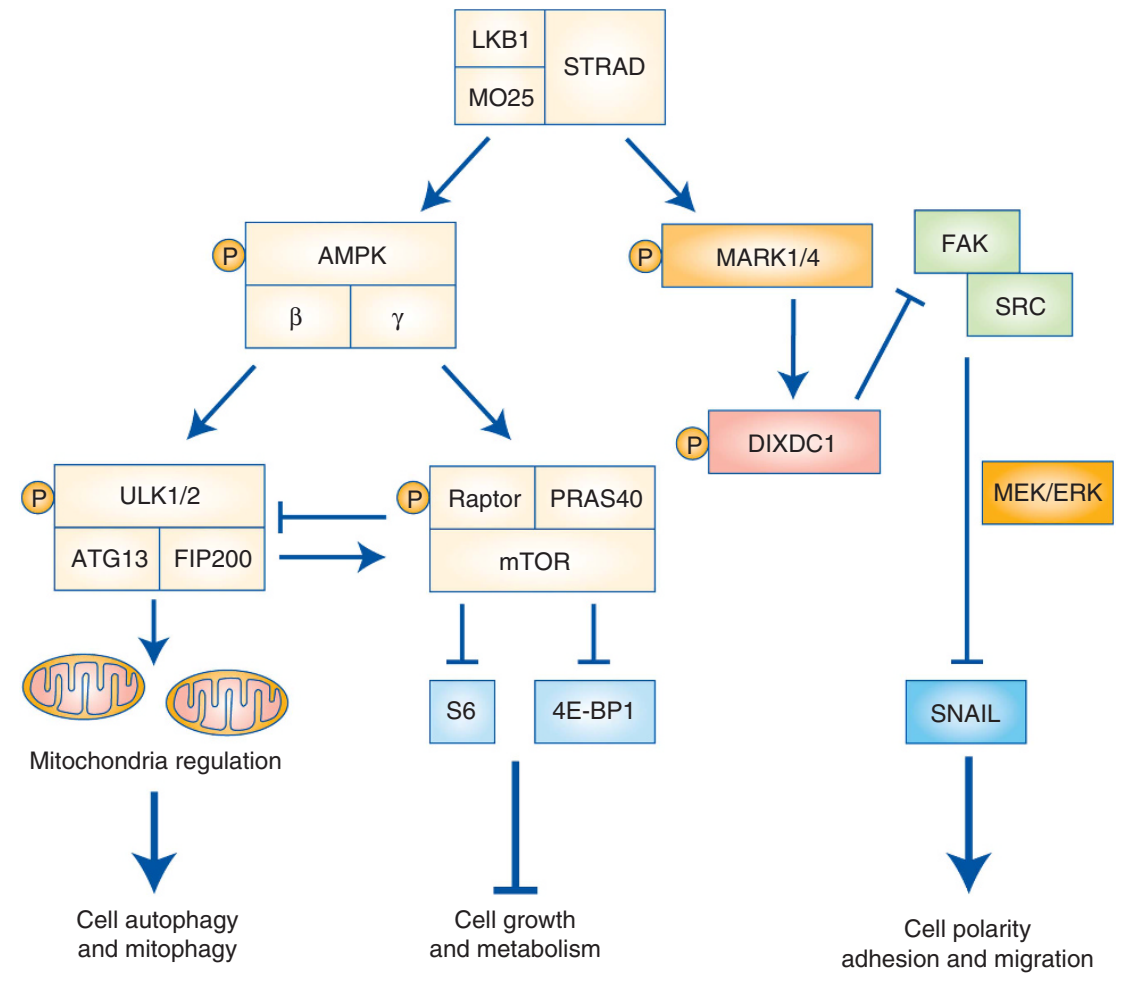

Figure 3. LKB1 regulation of AMPK and MARK signalling pathways. Phosphorylation of AMPK leads to phosphorylation of ULK1/2 and Raptor. As a result of phosphorylation of ULK1/2, autophagy and mitophagy are upregulated. Phosphorylation of Raptor by AMPK leads to downregulation of mTOR activity and its downstream targets S6 and 4E-BP1. LKB1 phosphorylates MARK1/4 leading to phosphorylation of DIXDC1 and inhibition of SNAIL protein through regulation of FAK and SRC kinases controlling both cell adhesion and migration.

mitochondria. Subsequent analysis of LKB1 ${ }^{-1-}$ NSCLC tumour lines revealed inactivation of the AMPK-ULK1 signalling thus phenocopying the mitochondrial defects and reduced autophagy observed in Ampk ${ }^{-1-}$ and Ulk1 ${ }^{-/-}$murine embryonic fibroblasts (Shackelford et al, 2013b). These studies suggest that LKB1 inactivation and the resultant loss of AMPK-ULK1 signalling may lead to aberrant mitochondrial pools and decreased autophagy may compromise the ability of these tumours to supply cellular energetic demands through the TCA cycle. Autophagy was shown to be a critical source of nutrients to supply RAS-driven human tumours and $\mathrm{Braf}^{\mathrm{V} 600 \mathrm{E}}$-driven GEMMs of NSCLC (Guo et al, 2011; Strohecker et al, 2013). Using a synthetic lethal RNAi screening approach, White and colleagues identified KRAS and LKB1 comutant NSCLC tumours to be addicted to coatomer complex I (COPI)-dependent lysosome acidification that supplied macromolecules to the TCA cycle. KRAS/LKB1 mutant lung tumours were reliant on lysosomal degradation of macromolecules to fuel catabolic metabolism and showed sensitivity to inhibition of lysosomal maturation (Kim et al, 2013). Pharmacological activation of ER stress in Kras/Lkb1 mutant tumours resulted in unfolded protein response-mediated tumour cell death (Inge et al, 2014). These studies suggest that inhibiting autophagy, lysosomal acidification and inducing ER stress are vulnerabilities that may be effectively targeted in LKB1 mutant tumours.

\section{TARGETING MTORC1 HYPERACTIVATION IN LKB1} MUTANT TUMOURS

Allosteric mTORC1 inhibitors. LKB1 negatively regulates mTORC1 kinase activity through AMPK phosphorylation of TSC2 and Raptor, therefore, LKB1 inactivation results in mTORC1 hyperactivation (Inoki et al, 2003; Corradetti et al, 2004; Shaw et al, 2004a; Gwinn et al, 2008) (Figure 3). As a result, the inhibition of mTOR has been extensively tested as a therapeutic approach to target $\mathrm{LKB1}^{-1-}$ tumour cells and mouse models of cancer. Preclinical studies examining rapamycin in Lkb1-deficient mouse models of cancer have yielded mixed results. Spontaneously arising hamartomas in Lkb1 ${ }^{+/-}$mice responded well (Wei et al, 2008; Shackelford et al, 2009b). Translation of these studies to treat hamartomas clinically with rapalogs has proven successful in tuberous sclerosis and lymphangioleiomyomatosis patients with the MILES trial (Bissler et al, 2008; McCormack et al, 2011), whereas early phase clinical trial for PJS patients was terminated owing to low enrolment. Rapamycin as a single agent has been shown to potently inhibit the growth and viability of endometrial carcinomas, oviductal neoplasias and papillary bladder tumours in $\mathrm{Lkb1}^{-1-}$ and $\mathrm{Lkb1}^{-1-}$; Pten ${ }^{-1-}$ GEMMs (Contreras et al, 2010; Shorning et al, 2011; Tanwar et al, 2012), as well as reduce the number and confluence of melanocytic lesions in BrafV600E; LKB1 ${ }^{-1-}$ mice (Damsky et al, 2015), however, rapamycin failed to induce a therapeutic response in lung tumours from Kras ${ }^{\mathrm{G} 12 \mathrm{D}}$-driven LKB1-deficient GEMMs (Liang et al, 2010). Allosteric mTORC1 inhibitors have generally performed poorly in clinical trials as tumours do not sustain a durable response and become resistant likely owing to mTORC2AKT-mediated reactivation of mTORC1 (Wander et al, 2011). For patients with LKB1 mutant tumours receiving rapalogs, it will be important to define the appropriate genetic and molecular landscape that dictates either response or resistance.

mTOR catalytic kinase inhibitors. The mTOR catalytic kinase inhibitors that target both mTORC1 and mTORC2 or dual mTOR/ $\mathrm{PI} 3 \mathrm{~K}$ inhibitors are predicted to show greater clinical efficacy than rapalogs for the treatment of LKB1 mutant tumours (Apsel et al, 2008; Maira et al, 2008; Feldman et al, 2009). Treatment of Kras-driven, PI3KCA mutant murine lung tumours with the dual $\mathrm{PI} 3 \mathrm{~K} / \mathrm{mTOR}$ inhibitor BEZ235 resulted in the inhibition of 
both PI3K and mTOR signalling and regression of primary lung tumours (Engelman et al, 2008). However, for the Kras; $\mathrm{Lkb1}^{-1-}$ mouse lung tumour model, the PI3K/mTOR inhibitor BEZ235 was effective only when combined with the MEK inhibitor AZD2644 and dasatinib, inhibitor of Src-family of kinases (Carretero et al, 2010). Although LKB1 mutations are infrequent in breast cancer, PJS patients show an increased risk for the development of breast cancer (Sanchez-Cespedes, 2007). The mTOR catalytic kinase inhibitors AZD8055 successfully inhibited tumour growth in $\mathrm{Lkb1}^{-/-}$NIC mouse breast tumour model (Andrade-Vieira et al, 2014). Of interest, both rapamycin and the dual PI3K/mTOR inhibitor BEZ235 inhibited tumour growth in an Lkb1/Pten-deficient GEMM of endometrial cancer agreeing with a previous study that showed that single-therapy rapamycin effectively reduced tumour burden in Lkb1-deficient GEMM of endometrial ADC (Contreras et al, 2010; Cheng et al, 2014). Lastly, treatment of the Kras/Lkb1 GEMMs with the multi-target receptor tyrosine kinase inhibitor sunitinib (Sutent) was effective and reduced tumour size, increased tumour necrosis and slowed tumour progression in primary lesions demonstrating that receptor tyrosine kinases may be targeted in addition to the PI3K/mTOR pathway (Gandhi et al, 2009).

LKB1 SUBSTRATES - THE POTENTIAL OF OLD AND NEW THERAPEUTIC TARGETS

Adenosine monophosphate-activated protein kinase-like kinases. While deregulation of the AMPK pathway has received considerable attention, recently studies investigating AMPK's other siblings have made significant progress towards mapping the LKB1 signalling pathway. There has been considerable work to elucidate the function of AMPK-like kinases, however, much of this work has been performed on an LKB1 wild-type background. An increasing number of studies suggest that the 12 additional AMPKlike kinases that are phosphorylated by LKB1 do have an important role in cancer development and progression. BRISK1 and BRISK2 have roles in neural development, but a recent report showed that decreased expression in samples from breast cancer patients negatively correlates with clinical outcomes (Wang et al, 2014). High levels of expression of NUAK1 (ARK5) have been reported to correlate with poor prognosis in patients with hepatocellular carcinoma (Liu et al, 2012a; Cui et al, 2013), glioma ( $\mathrm{Lu}$ et al, 2013), colorectal cancer (Kusakai et al, 2004; Roh et al, 2010), multiple myeloma (Suzuki et al, 2005) and pancreatic cancer (Suzuki et al, 2004). Reports on the role of NUAK2 in tumours of different origin vary: in melanoma, NUAK2 (SNARK) levels correlate negatively with patient survival (Namiki et al, 2011), whereas in ovarian cancer patients, an opposite trend was reported (Emmanuel et al, 2011). SIK1, SIK2 (QIK) and SIK3 (QSK) have been reported to have a role in metastasis in gastric ADCs (Selvik et al, 2014) and mitotic progression in prostate and ovarian cancers (Ahmed et al, 2010; Chen et al, 2014; Bon et al, 2015). Additionally, SIK1 was shown to be required for P53-dependent anoikis, and RNAi-mediated gene silencing of SIK1 resulted in increased lung micrometastases in xenografts injected with transformed human mammary epithelial cells. Expression of conditionally active SIK1 in LKB1 mutant A549 cell lines suppressed invasion and pulmonary metastasis, thus implicating an important role for the SIK1 in progression and metastasis of LKB1-deficient tumours (Cheng et al, 2009). The maternal embryonic leucine-zipper kinase (MELK) expression negatively correlates with patient survival in cases of acute myeloid leukaemia (Alachkar et al, 2014), gastric cancer progression (Du et al, 2014), high grade prostate cancer (Kuner et al, 2013) and breast cancer (Pickard et al, 2009). Finally, SNRK levels have been reported to be higher in colon cancer lines compared with normal cells (Rines et al, 2012).

Recent studies point to deregulation of the group of AMPK-like kinases called MAP/microtubule affinity-regulating kinases 1-4 (MARKs1-4; also known as PAR1) following LKB1 inactivation as having an integral role in metastasis. The link between deregulation of MARKs and metastasis is important because the inactivation of Lkb1 promotes metastasis in the Kras ${ }^{\mathrm{G} 12 \mathrm{D}}$ mouse model of lung cancer; however, the exact mechanism(s) have not been uncovered (Ji et al, 2007). The MARKs are cellular regulators of polarity and are conserved from yeast to mammals (MartinBelmonte and Perez-Moreno, 2012). A recent study investigating downstream substrates of the MARK kinase family, identified DIXDC1, a scaffold protein that localises to focal adhesions as a direct target of MARK1 and of MARK4 (Goodwin et al, 2014) (Figure 3). Inactivation of LKB1 resulted in an AMPK-independent increase in levels of Snaill that were dependent on MARK1 and MARK4. The authors demonstrate that inactivation of the LKB1MARK-DIXDC1 signalling axis resulted in the activation of FAK and SRC. Activation of FAK led to MEK/ERK-dependent upregulation of SNAIL resulting in increased cell migration and invasion in vitro and in vivo in lung colonisation assay. Low DIXDC1 expression significantly correlated with decreased NSCLC patient overall survival suggesting that the MARK kinase family and DIXDC1 are important clinical biomarkers in cancer. Additionally, it was shown that the loss of LKB1 results in FAK phosphorylation that can be repressed by re-expressing LKB1 or by treating cells with FAK inhibitor PF-573228 (Kline et al, 2013). This study links an earlier study by Carretero et al (2010) who demonstrated that LKB1 mutant NSCLC tumour cell lines are sensitive to RNAi-mediated silencing of FAK and SRC. Treatment of Kras ${ }^{\mathrm{G} 12 \mathrm{D}}$-driven, $\mathrm{Lkb1}^{-1-}$ (Kras/Lkb1) mouse models of lung cancer with the combination of the SRC inhibitor dasatinib, MEK inhibitor AZD6244, and the dual PIK3CA and mTOR inhibitor BEZ235 resulted in decreased primary and metastatic lung tumours (Carretero et al, 2010). Similar results were observed in a mouse melanoma model, where loss of LKB1 correlated with increased phosphorylation of SRC Family Kinase (SFK) Yes, which resulted in increased cell migration and invasion. Pan-SFK inhibitor dasatinib did not inhibit tumour metastasis in vivo owing to inadequate inhibition of Yes kinase (Liu et al, 2012a,b). Lastly, a genetic screen identified that the LKB1/MARK signalling axis regulates the Hippo (MST1/2 in humans) Yap pathway. Activation of YAP was consistently seen in Lkb1-deficient human PJS polyps and tumours as well as in mouse models of NSCLC and pancreatic ductal ADC (Mohseni et al, 2014). In sum, these studies demonstrate MARK1 kinases as important regulators of metastatic potential.

\section{PRECLINICAL MODELS FOR LKB1-DEFICIENT TUMOURS}

Lkb1-deficient mouse models of cancer. Germ-line and conditional deletion of $l k b 1$ in mice have confirmed that LKB1 inactivation has an important role in tumourigenesis in a variety of tissues. Genetically engineered mouse models have proven to be a valuable tool to understand the molecular basis of disease following inactivation of LKB1. Biallelic loss of $l k b 1$ is embryonic lethal in mice, yet, heterozygous $\mathrm{lkb}^{+/-}$mice develop gastrointestinal hamartomas that closely recapitulate the pathophysiology of the PJS patients (Ylikorkala et al, 2001; Bardeesy et al, 2002; Jishage et al, 2002; Miyoshi et al, 2002; Rossi et al, 2002; Katajisto et al, 2008). Conditional, biallelic deletion of $l k b 1$ in the lung tissue accelerated Kras ${ }^{\mathrm{G} 12 \mathrm{D}}$-driven lung tumours in mice and led to heterogeneous tumour development of ADC, squamous and large cell carcinomas that closely mirror the human disease (Ji et al, 
2007). Conditional inactivation of $l k b 1$ in a number of tissues in mice have generated tumours in breast, pancreas, prostate, skin and bone. (For reviews, see (Ollila and Makela, 2011; Shackelford, 2013). The accuracy of these mouse models to human disease is an important contributing element to the advances the field of LKB1 research has made in the last decade and a half.

Patient-derived xenografts and organoid models. In addition to GEMMs, integrating patient-derived xenografts (PDXs) models will provide comprehensive in vivo models to study LKB1 inactivation in primary human tumours. Patient-derived xenograft models take with great efficiency in cancer with frequent LKB1 mutations such as NSCLC, pancreas and colon ( Fu et al, 1991, 1992) (Gandara et al, 2015) and patient-derived cell lines are amenable to 3D culture (Zhang et al, 2012). Identification of LKB1 inactivation in PDX models will require deep sequencing and/or functional studies. Additionally, organoid models in colon and pancreatic ADC have been established, and it is likely these models could be used to successfully bridge in vitro and in vivo studies of Li et al (2014) and Boj et al (2015).

The advent of the co-clinical trial. The use of GEMMs in coclinical studies may provide an efficient platform to begin evaluating single and combination therapies to which Lkb1deficient tumours are both responsive and resistant. Seminal studies published in recent years have effectively integrated the use of GEMMs to mirror human clinical trials for NSCLC and acute promyelocytic leukaemia (Nardella et al, 2011). In a seminal study by Chen et al (2012), Kras ${ }^{\mathrm{G} 12 \mathrm{D}}$-driven GEMMs were used in a coclinical trial testing the combination of docetaxol + selumetinib in patients identified as having lung tumours positive for KRAS mutations. The authors stratified patients by KRAS single mutation and KRAS/LKB1 or KRAS/P53 co-mutations and mirrored human

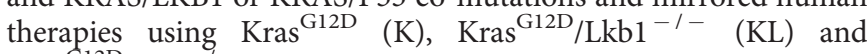
$\mathrm{Kras}^{\mathrm{G} 12 \mathrm{D}} / \mathrm{p}^{2} 3^{-1-}$ (KP) GEMMs. Surprisingly, the authors discovered that $\mathrm{K}$ and $\mathrm{KP}$ lung tumours were responsive to docetaxol + selumetinib therapy, whereas KL tumours were unresponsive to therapy. Detailed molecular analysis revealed low activation of the MEK/ERK pathway in KL lung nodules, thus explaining the lack of therapeutic response. Interestingly, in a separate pre-clinical study comparing the response of $\mathrm{K}, \mathrm{KL}$ and KP GEMMs to phenformin, it was discovered that KL tumours showed a significant response to phenformin, while K and KP lung tumours remained resistant, thus demonstrating that Lkb1 inactivation determined sensitivity to phenformin (Shackelford et al, 2013a). These studies underscore the importance of stratifying lung tumours by genetic mutations and incorporating GEMMs as an integral part of co-clinical trials.

\section{LOOKING FORWARD - IDENTIFYING NEW PATHWAYS TO TARGET}

Continuing our understanding on how LKB1 inactivation deregulates basic cellular functions such as metabolism and growth will be an important next step. A synthetic lethal screen performed on Kras/p53/Lkb1 mutant GEMM derived NSCLC tumour lines and identified Deoxythymidylate kinase as a top hit thus coupling LKB1 inactivation to dependency on folate metabolism in order to supply nucleotides required for cellular replication (Liu et al, 2013). The extracellular matrix remodelling protein lysyl oxidase was found to be highly elevated in Kras/Lkb1 GEMMs and inhibition of lysyl oxidase with BAPN also impaired tumour progression (Gao et al, 2010). Future studies are needed to comprehensively profile the intracellular tumour environment such as metabolism as well as the extracellular microenvironment and such studies will likely shed light on new tumour vulnerabilities that occur following LKB1 loss.
As with any therapy, we expect that some cells within tumours will develop resistance to LKB1-targeted therapy. Specific resistance mechanism would depend on the therapy used. Because the majority of therapies targeting LKB1 vulnerabilities concentrate on disrupting metabolism at some cellular level, one could predict that metabolic adaptation will be the likely course of resistance in $\mathrm{LKB} 1^{-/-}$tumours. While resistance to targeted therapies such as mTOR inhibitors are likely to follow canonical pathways such as activation of AKT or mTORC2, metabolic-based therapies will induce metabolic adaptation (O'Reilly et al, 2006; RodrikOutmezguine et al, 2011). Therefore, it will be necessary to map the metabolic dependencies in LKB1 mutant tumours in order to identify and predict metabolic resistance. For example, resistance to biguanides that target complex I of ETC induce a metabolic increase in glycolytic metabolism (Dykens et al, 2008; Shackelford et al, 2013a). In vitro cell-based screens using $2 \mathrm{D}$ and $3 \mathrm{D}$ cell culture and possibly organoids could be set up with cells exposed to targeted therapies for prolonged time allowing for resistance to develop. Coupling gene expression to analysis of signal transduction and metabolic pathways would provide a rapid and robust means to identify novel and canonical resistance mechanisms that could be tested in vivo.

Combining therapy targeting LKB1 tumours with currently available chemotherapy is an area that is unexplored and needs to be addressed by the field. To date, no study has been performed to identify specific chemotherapies that selectively target $\mathrm{LKB} 1^{-/-}$ tumours, however, large-scale analyses such as the cancer cell line encyclopaedia represent studies that may offer clues (Barretina et al, 2012). Identification of novel strategies that combine chemotherapy with targeted or metabolic therapies that are both effective and carry low toxicities may be clinically beneficial.

The anti-PD-1 agent nivolumab was recently FDA-approved for the treatment of squamous cell lung cancer. Immunotherapy therapies targeting PD1 and PDL1 in NSCLC have shown great promise in the clinic (Topalian et al, 2012; Xu et al, 2014). AntiPD-1 and PD-L1 therapies may prove effective against LKB1 mutant squamous lung tumours as a recent study describing an Lkb1/Pten-deficient GEMM of squamous cell lung cancer found that tumours expressed high PD-L1 levels (Xu et al, 2014). Combination therapies adding together different therapeutic approaches such as targeted therapies, metabolic therapies and immunotherapies are likely to yield the best clinical results and may be tested pre-clinically using Lkb1-deficient GEMMs.

An additional step of stratification and treatment of LKB1deficient tumours may be to group them with co-mutations that frequently arise in genes such as KRAS and BRG1 (Carretero et al, 2004; Medina et al, 2008). A recent study described an allosteric irreversible small molecule inhibitor, compound 12, that selectively binds to the cysteine of oncogenic $\mathrm{KRAS}^{\mathrm{G} 12 \mathrm{C}}$ resulting in preferential growth inhibition and apoptosis of KRAS ${ }^{\mathrm{G} 12 \mathrm{C}}$ mutant tumour lines (Ostrem et al, 2013). Functional epigenetic studies in lung ADC identified BRM/SMARCA2 and EZH2 potential targets in BRG1 mutant lung tumours (Hoffman et al, 2014; Fillmore et al, 2015). Future studies examining the combination of novel inhibitors of KRAS or of epigenetic regulators in combination with energy stress agents and/or targeted therapies may prove an effective strategy for targeting tumours for LKB1/KRAS ${ }^{\mathrm{G} 12 \mathrm{C}}$ or LKB1/BRG1 co-mutated tumours.

\section{CONCLUDING REMARKS}

Work from preclinical studies in cell lines, xenografts and GEMMs predict that metabolic therapies, targeted therapeutics targeting LKB1 vulnerabilities will be most effective in combination. Immunotherapies have gained considerable traction as highly 
effective therapies and were recently approved for the treatment of melanoma and NSCLC. Achieving personalised treatments for patients harbouring LKB1 mutations will require defining vulnerabilities, identifying effective drugs that target these vulnerabilities and identifying appropriate research platform(s) to test novel therapeutics in vivo.

As every single approach has its limitations, it is reasonable to assume that systematic and efficient translation of new therapies targeting LKB1 vulnerabilities will require the development and integration of both cell-based and mouse-based research platforms. The use of $2 \mathrm{D}$ and $3 \mathrm{D}$ culture systems as well as the development of organoid models hold promise for accurately bridging in vitro and in vivo studies. Novel combination therapies targeting LKB1 vulnerabilities in cancer will need to be rigorously tested in both cell-culture-based and animal models. Because most tumours eventually develop resistance to therapy, it will be important to choose pre-clinical in vivo models that readily develop resistance and accurately model the heterogeneity present in most tumours. Although xenografts remain a highly effective in vivo means to screen isogenic tumour lines, they should be used in combination with autochthonous models such as GEMMs or with PDXs. This will likely facilitate defined treatment modalities that selectively target this large subset of tumours. Finally, using imaging-based preclinical studies in animal models, such as GEMMs and PDXs, to rigorously test new therapeutic strategies hold great promise for efficiently translating novel drugs that target LKB1 vulnerabilities into clinical trials (de Jong et al, 2014).

\section{CONFLICT OF INTEREST}

The authors declare no conflict of interest.

\section{REFERENCES}

Ahmed AA, Lu Z, Jennings NB, Etemadmoghadam D, Capalbo L, Jacamo RO, Barbosa-Morais N, Le XF. Australian Ovarian Cancer Study GVivas-Mejia P, Lopez-Berestein G, Grandjean G, Bartholomeusz G, Liao W, Andreeff M, Bowtell D, Glover DM, Sood AK, Bast Jr RC (2010) SIK2 is a centrosome kinase required for bipolar mitotic spindle formation that provides a potential target for therapy in ovarian cancer. Cancer Cell 18: 109-121.

Alachkar H, Mutonga MB, Metzeler KH, Fulton N, Malnassy G, Herold T, Spiekermann K, Bohlander SK, Hiddemann W, Matsuo Y, Stock W, Nakamura Y (2014) Preclinical efficacy of maternal embryonic leucinezipper kinase (MELK) inhibition in acute myeloid leukemia. Oncotarget 5: $12371-12382$

Algire C, Amrein L, Bazile M, David S, Zakikhani M, Pollak M (2011) Diet and tumor LKB1 expression interact to determine sensitivity to antineoplastic effects of metformin in vivo. Oncogene 30: 1174-1182.

Andrade-Vieira R, Goguen D, Bentley HA, Bowen CV, Marignani PA (2014) Pre-clinical study of drug combinations that reduce breast cancer burden due to aberrant mTOR and metabolism promoted by LKB1 loss. Oncotarget 5: 12738-12752.

Anisimov VN, Berstein LM, Egormin PA, Piskunova TS, Popovich IG, Zabezhinski MA, Kovalenko IG, Poroshina TE, Semenchenko AV, Provinciali M, Re F, Franceschi C (2005) Effect of metformin on life span and on the development of spontaneous mammary tumors in HER-2/neu transgenic mice. Exp Gerontol 40: 685-693.

Apsel B, Blair JA, Gonzalez B, Nazif TM, Feldman ME, Aizenstein B, Hoffman R, Williams RL, Shokat KM, Knight ZA (2008) Targeted polypharmacology: discovery of dual inhibitors of tyrosine and phosphoinositide kinases. Nat Chem Biol 4: 691-699.

Bardeesy N, Sinha M, Hezel AF, Signoretti S, Hathaway NA, Sharpless NE, Loda M, Carrasco DR, DePinho RA (2002) Loss of the Lkb1 tumour suppressor provokes intestinal polyposis but resistance to transformation. Nature 419: 162-167.

Barretina J, Caponigro G, Stransky N, Venkatesan K, Margolin AA, Kim S, Wilson CJ, Lehar J, Kryukov GV, Sonkin D, Reddy A, Liu M, Murray L, Berger MF, Monahan JE, Morais P, Meltzer J, Korejwa A, Jane-Valbuena J,
Mapa FA, Thibault J, Bric-Furlong E, Raman P, Shipway A, Engels IH, Cheng J, Yu GK, Yu J, Aspesi Jr P, de Silva M, Jagtap K, Jones MD, Wang L, Hatton C, Palescandolo E, Gupta S, Mahan S, Sougnez C, Onofrio RC, Liefeld T, MacConaill L, Winckler W, Reich M, Li N, Mesirov JP, Gabriel SB, Getz G, Ardlie K, Chan V, Myer VE, Weber BL, Porter J, Warmuth M, Finan P, Harris JL, Meyerson M, Golub TR, Morrissey MP, Sellers WR, Schlegel R, Garraway LA (2012) The Cancer Cell Line Encyclopedia enables predictive modelling of anticancer drug sensitivity. Nature 483: 603-607.

Bissler JJ, McCormack FX, Young LR, Elwing JM, Chuck G, Leonard JM, Schmithorst VJ, Laor T, Brody AS, Bean J, Salisbury S, Franz DN (2008) Sirolimus for angiomyolipoma in tuberous sclerosis complex or lymphangioleiomyomatosis. N Engl J Med 358: 140-151.

Boj SF, Hwang CI, Baker LA, Chio, Engle DD, Corbo V, Jager M, Ponz-Sarvise M, Tiriac H, Spector MS, Gracanin A, Oni T, Yu KH, van Boxtel R, Huch M, Rivera KD, Wilson JP, Feigin ME, Ohlund D, Handly-Santana A, Ardito-Abraham CM, Ludwig M, Elyada E, Alagesan B, Biffi G, Yordanov GN, Delcuze B, Creighton B, Wright K, Park Y, Morsink FH, Molenaar IQ, Borel Rinkes IH, Cuppen E, Hao Y, Jin Y, Nijman IJ, Iacobuzio-Donahue C, Leach SD, Pappin DJ, Hammell M, Klimstra DS, Basturk O, Hruban RH, Offerhaus GJ, Vries RG, Clevers H, Tuveson DA (2015) Organoid models of human and mouse ductal pancreatic cancer. Cell 160: 324-338.

Bon H, Wadhwa K, Schreiner A, Osborne M, Carroll T, Ramos-Montoya A, Ross-Adams H, Visser M, Hoffmann R, Ahmed AA, Neal DE, Mills IG (2015) Salt-inducible kinase 2 regulates mitotic progression and transcription in prostate cancer. Mol Cancer Res 13: 620-635.

Bowker SL, Majumdar SR, Veugelers P, Johnson JA (2006) Increased cancer-related mortality for patients with type 2 diabetes who use sulfonylureas or insulin. Diabetes Care 29: 254-258.

Carretero J, Medina PP, Pio R, Montuenga LM, Sanchez-Cespedes M (2004) Novel and natural knockout lung cancer cell lines for the LKB1/STK11 tumor suppressor gene. Oncogene 23: 4037-4040.

Carretero J, Shimamura T, Rikova K, Jackson AL, Wilkerson MD, Borgman CL, Buttarazzi MS, Sanofsky BA, McNamara KL, Brandstetter KA, Walton ZE, Gu TL, Silva JC, Crosby K, Shapiro GI, Maira SM, Ji H, Castrillon DH, Kim CF, Garcia-Echeverria C, Bardeesy N, Sharpless NE, Hayes ND, Kim WY, Engelman JA, Wong KK (2010) Integrative genomic and proteomic analyses identify targets for Lkbl-deficient metastatic lung tumors. Cancer Cell 17: 547-559.

Chen H, Huang S, Han X, Zhang J, Shan C, Tsang YH, Ma HT, Poon RY (2014) Salt-inducible kinase 3 is a novel mitotic regulator and a target for enhancing antimitotic therapeutic-mediated cell death. Cell Death Dis 5: e1177.

Chen Z, Cheng K, Walton Z, Wang Y, Ebi H, Shimamura T, Liu Y, Tupper T, Ouyang J, Li J, Gao P, Woo MS, Xu C, Yanagita M, Altabef A, Wang S, Lee C, Nakada Y, Pena CG, Sun Y, Franchetti Y, Yao C, Saur A, Cameron MD, Nishino M, Hayes DN, Wilkerson MD, Roberts PJ, Lee CB, Bardeesy N, Butaney M, Chirieac LR, Costa DB, Jackman D, Sharpless NE, Castrillon DH, Demetri GD, Janne PA, Pandolfi PP, Cantley LC, Kung AL, Engelman JA, Wong KK (2012) A murine lung cancer co-clinical trial identifies genetic modifiers of therapeutic response. Nature 483: 613-617.

Cheng H, Liu P, Wang ZC, Zou L, Santiago S, Garbitt V, Gjoerup OV, Iglehart JD, Miron A, Richardson AL, Hahn WC, Zhao JJ (2009) SIK1 couples LKB1 to p53-dependent anoikis and suppresses metastasis. Sci Signal 2: ra35.

Cheng H, Liu P, Zhang F, Xu E, Symonds L, Ohlson CE, Bronson RT, Maira SM, Di Tomaso E, Li J, Myers AP, Cantley LC, Mills GB, Zhao JJ (2014) A genetic mouse model of invasive endometrial cancer driven by concurrent loss of Pten and Lkb1 Is highly responsive to mTOR inhibition. Cancer Res 74: 15-23.

Contreras CM, Akbay EA, Gallardo TD, Haynie JM, Sharma S, Tagao O, Bardeesy N, Takahashi M, Settleman J, Wong KK, Castrillon DH (2010) Lkb1 inactivation is sufficient to drive endometrial cancers that are aggressive yet highly responsive to mTOR inhibitor monotherapy. Dis Model Mech 3: 181-193.

Corradetti MN, Inoki K, Bardeesy N, DePinho RA, Guan KL (2004) Regulation of the TSC pathway by LKB1: evidence of a molecular link between tuberous sclerosis complex and Peutz-Jeghers syndrome. Genes Dev 18: 1533-1538.

Crofford OB (1995) Metformin. N Engl J Med 333: 588-589.

Cui J, Yu Y, Lu GF, Liu C, Liu X, Xu YX, Zheng PY (2013) Overexpression of ARK5 is associated with poor prognosis in hepatocellular carcinoma. Tumour Biol 34: 1913-1918. 
Currie CJ, Poole CD, Jenkins-Jones S, Gale EA, Johnson JA, Morgan CL (2012) Mortality after incident cancer in people with and without type 2 diabetes: impact of metformin on survival. Diabetes Care 35: 299-304.

Damsky W, Micevic G, Meeth K, Muthusamy V, Curley DP, Santhanakrishnan M, Erdelyi I, Platt JT, Huang L, Theodosakis N, Zaidi MR, Tighe S, Davies MA, Dankort D, McMahon M, Merlino G, Bardeesy N, Bosenberg M (2015) mTORC1 activation blocks BrafV600Einduced growth arrest but is insufficient for melanoma formation. Cancer Cell 27: 41-56.

de Jong M, Essers J, van Weerden WM (2014) Imaging preclinical tumour models: improving translational power. Nat Rev Cancer 14: 481-493.

Ding L, Getz G, Wheeler DA, Mardis ER, McLellan MD, Cibulskis K, Sougnez C, Greulich H, Muzny DM, Morgan MB, Fulton L, Fulton RS, Zhang Q, Wendl MC, Lawrence MS, Larson DE, Chen K, Dooling DJ, Sabo A, Hawes AC, Shen H, Jhangiani SN, Lewis LR, Hall O, Zhu Y, Mathew T, Ren Y, Yao J, Scherer SE, Clerc K, Metcalf GA, Ng B, Milosavljevic A, Gonzalez-Garay ML, Osborne JR, Meyer R, Shi X, Tang Y, Koboldt DC, Lin L, Abbott R, Miner TL, Pohl C, Fewell G, Haipek C, Schmidt H, Dunford-Shore BH, Kraja A, Crosby SD, Sawyer CS, Vickery T, Sander S, Robinson J, Winckler W, Baldwin J, Chirieac LR, Dutt A, Fennell T, Hanna M, Johnson BE, Onofrio RC, Thomas RK, Tonon G, Weir BA, Zhao X, Ziaugra L, Zody MC, Giordano T, Orringer MB, Roth JA, Spitz MR, Wistuba, Ozenberger B, Good PJ, Chang AC, Beer DG, Watson MA, Ladanyi M, Broderick S, Yoshizawa A, Travis WD, Pao W, Province MA, Weinstock GM, Varmus HE, Gabriel SB, Lander ES, Gibbs RA, Meyerson M, Wilson RK (2008) Somatic mutations affect key pathways in lung adenocarcinoma. Nature 455: 1069-1075.

Dowling RJ, Niraula S, Stambolic V, Goodwin PJ (2012) Metformin in cancer: translational challenges. J Mol Endocrinol 48: R31-R43.

Druker BJ, Sawyers CL, Kantarjian H, Resta DJ, Reese SF, Ford JM, Capdeville R, Talpaz M (2001) Activity of a specific inhibitor of the BCR-ABL tyrosine kinase in the blast crisis of chronic myeloid leukemia and acute lymphoblastic leukemia with the Philadelphia chromosome. $N$ Engl J Med 344: 1038-1042.

Du T, Qu Y, Li J, Li H, Su L, Zhou Q, Yan M, Li C, Zhu Z, Liu B (2014) Maternal embryonic leucine zipper kinase enhances gastric cancer progression via the FAK/Paxillin pathway. Mol Cancer 13: 100.

Dykens JA, Jamieson J, Marroquin L, Nadanaciva S, Billis PA, Will Y (2008) Biguanide-induced mitochondrial dysfunction yields increased lactate production and cytotoxicity of aerobically-poised HepG2 cells and human hepatocytes in vitro. Toxicol Appl Pharmacol 233: 203-210.

Egan DF, Shackelford DB, Mihaylova MM, Gelino S, Kohnz RA, Mair W, Vasquez DS, Joshi A, Gwinn DM, Taylor R, Asara JM, Fitzpatrick J, Dillin A, Viollet B, Kundu M, Hansen M, Shaw RJ (2011) Phosphorylation of ULK1 (hATG1) by AMP-activated protein kinase connects energy sensing to mitophagy. Science 331: 456-461.

Emmanuel C, Gava N, Kennedy C, Balleine RL, Sharma R, Wain G, Brand A, Hogg R, Etemadmoghadam D, George J. Australian Ovarian Cancer Study GBirrer MJ, Clarke CL, Chenevix-Trench G, Bowtell DD, Harnett PR, deFazio A (2011) Comparison of expression profiles in ovarian epithelium in vivo and ovarian cancer identifies novel candidate genes involved in disease pathogenesis. PLoS One 6: el7617.

Engelman JA, Chen L, Tan X, Crosby K, Guimaraes AR, Upadhyay R, Maira M, McNamara K, Perera SA, Song Y, Chirieac LR, Kaur R, Lightbown A, Simendinger J, Li T, Padera RF, Garcia-Echeverria C, Weissleder R, Mahmood U, Cantley LC, Wong KK (2008) Effective use of PI3K and MEK inhibitors to treat mutant Kras G12D and PIK3CA H1047R murine lung cancers. Nat Med 14: 1351-1356.

Evans JM, Donnelly LA, Emslie-Smith AM, Alessi DR, Morris AD (2005) Metformin and reduced risk of cancer in diabetic patients. BMJ 330: 1304-1305.

Feldman ME, Apsel B, Uotila A, Loewith R, Knight ZA, Ruggero D, Shokat KM (2009) Active-site inhibitors of mTOR target rapamycinresistant outputs of mTORC1 and mTORC2. PLoS Biol 7: e38.

Fernandez P, Carretero J, Medina PP, Jimenez AI, Rodriguez-Perales S, Paz MF, Cigudosa JC, Esteller M, Lombardia L, Morente M, Sanchez-Verde L, Sotelo T, Sanchez-Cespedes M (2004) Distinctive gene expression of human lung adenocarcinomas carrying LKB1 mutations. Oncogene 23: 5084-5091.

Fillmore CM, Xu C, Desai PT, Berry JM, Rowbotham SP, Lin YJ, Zhang H, Marquez VE, Hammerman PS, Wong KK, Kim CF (2015) EZH2 inhibition sensitizes BRG1 and EGFR mutant lung tumours to TopoII inhibitors. Nature 520: 239-242.
Fimognari FL, Pastorelli R, Incalzi RA (2006) Phenformin-induced lactic acidosis in an older diabetic patient: a recurrent drama (phenformin and lactic acidosis). Diabetes Care 29: 950-951.

Fu X, Guadagni F, Hoffman RM (1992) A metastatic nude-mouse model of human pancreatic cancer constructed orthotopically with histologically intact patient specimens. Proc Natl Acad Sci USA 89: 5645-5649.

Fu XY, Besterman JM, Monosov A, Hoffman RM (1991) Models of human metastatic colon cancer in nude mice orthotopically constructed by using histologically intact patient specimens. Proc Natl Acad Sci USA 88: 9345-9349.

Gan B, Hu J, Jiang S, Liu Y, Sahin E, Zhuang L, Fletcher-Sananikone E, Colla S, Wang YA, Chin L, Depinho RA (2010) Lkb1 regulates quiescence and metabolic homeostasis of haematopoietic stem cells. Nature 468 : 701-704.

Gandara DR, Mack PC, Bult C, Li T, Lara Jr PN, Riess JW, Astrow SH, Gandour-Edwards R, Cooke DT, Yoneda KY, Moore EH, Pan CX, Burich RA, David EA, Keck JG, Airhart S, Goodwin N, de Vere White RW, Liu ET (2015) Bridging tumor genomics to patient outcomes through an integrated patient-derived xenograft platform. Clin Lung Cancer 16: $165-172$.

Gandhi L, McNamara KL, Li D, Borgman CL, McDermott U, Brandstetter KA, Padera RF, Chirieac LR, Settleman JE, Wong KK (2009) Sunitinib prolongs survival in genetically engineered mouse models of multistep lung carcinogenesis. Cancer Prev Res (Phila) 2: 330-337.

Gao Y, Xiao Q, Ma H, Li L, Liu J, Feng Y, Fang Z, Wu J, Han X, Zhang J, Sun Y, Wu G, Padera R, Chen H, Wong KK, Ge G, Ji H (2010) LKB1 inhibits lung cancer progression through lysyl oxidase and extracellular matrix remodeling. Proc Natl Acad Sci USA 107: 18892-18897.

Goodwin JM, Svensson RU, Lou HJ, Winslow MM, Turk BE, Shaw RJ (2014) An AMPK-independent signaling pathway downstream of the LKB1 tumor suppressor controls Snaill and metastatic potential. Mol Cell 55: 436-450.

Gorboulev V, Ulzheimer JC, Akhoundova A, Ulzheimer-Teuber I, Karbach U, Quester S, Baumann C, Lang F, Busch AE, Koepsell H (1997) Cloning and characterization of two human polyspecific organic cation transporters. DNA Cell Biol 16: 871-881.

Guo JY, Chen HY, Mathew R, Fan J, Strohecker AM, Karsli-Uzunbas G, Kamphorst JJ, Chen G, Lemons JM, Karantza V, Coller HA, Dipaola RS, Gelinas C, Rabinowitz JD, White E (2011) Activated Ras requires autophagy to maintain oxidative metabolism and tumorigenesis. Genes Dev 25: 460-470.

Gurumurthy S, Xie SZ, Alagesan B, Kim J, Yusuf RZ, Saez B, Tzatsos A, Ozsolak F, Milos P, Ferrari F, Park PJ, Shirihai OS, Scadden DT, Bardeesy N (2010) The Lkb1 metabolic sensor maintains haematopoietic stem cell survival. Nature 468: 659-663.

Gwinn DM, Shackelford DB, Egan DF, Mihaylova MM, Mery A, Vasquez DS, Turk BE, Shaw RJ (2008) AMPK phosphorylation of raptor mediates a metabolic checkpoint. Mol Cell 30: 214-226.

Hardie DG, Carling D, Gamblin SJ (2011) AMP-activated protein kinase: also regulated by ADP? Trends Biochem Sci 36: 470-477.

Hardie DG, Ross FA, Hawley SA (2012) AMPK: a nutrient and energy sensor that maintains energy homeostasis. Nat Rev Mol Cell Biol 13: 251-262.

Hawley SA, Boudeau J, Reid JL, Mustard KJ, Udd L, Makela TP, Alessi DR, Hardie DG (2003) Complexes between the LKB1 tumor suppressor, STRADalpha/beta and MO25alpha/beta are upstream kinases in the AMP-activated protein kinase cascade. J Biol 2: 28.

Hawley SA, Pan DA, Mustard KJ, Ross L, Bain J, Edelman AM, Frenguelli BG, Hardie DG (2005) Calmodulin-dependent protein kinase kinase-beta is an alternative upstream kinase for AMP-activated protein kinase. Cell Metab 2: 9-19.

Hawley SA, Ross FA, Chevtzoff C, Green KA, Evans A, Fogarty S, Towler MC, Brown LJ, Ogunbayo OA, Evans AM, Hardie DG (2010) Use of cells expressing gamma subunit variants to identify diverse mechanisms of AMPK activation. Cell Metab 11: 554-565.

Hayer-Zillgen M, Bruss M, Bonisch H (2002) Expression and pharmacological profile of the human organic cation transporters hOCT1, hOCT2 and hOCT3. Br J Pharmacol 136: 829-836.

Hemminki A (1999) The molecular basis and clinical aspects of Peutz-Jeghers syndrome. Cell Mol Life Sci 55: 735-750.

Hemminki A, Markie D, Tomlinson I, Avizienyte E, Roth S, Loukola A, Bignell G, Warren W, Aminoff M, Hoglund P, Jarvinen H, Kristo P, Pelin K, Ridanpaa M, Salovaara R, Toro T, Bodmer W, Olschwang S, Olsen AS, Stratton MR, de la Chapelle A, Aaltonen LA (1998) A serine/ 
threonine kinase gene defective in Peutz-Jeghers syndrome. Nature 391: 184-187.

Hoffman GR, Rahal R, Buxton F, Xiang K, McAllister G, Frias E, Bagdasarian L, Huber J, Lindeman A, Chen D, Romero R, Ramadan N, Phadke T, Haas K, Jaskelioff M, Wilson BG, Meyer MJ, Saenz-Vash V, Zhai H, Myer VE, Porter JA, Keen N, McLaughlin ME, Mickanin C, Roberts CW, Stegmeier F, Jagani Z (2014) Functional epigenetics approach identifies BRM/SMARCA2 as a critical synthetic lethal target in BRG1-deficient cancers. Proc Natl Acad Sci USA 111: 3128-3133.

Hong SP, Leiper FC, Woods A, Carling D, Carlson M (2003) Activation of yeast Snf1 and mammalian AMP-activated protein kinase by upstream kinases. Proc Natl Acad Sci USA 100: 8839-8843.

Hurley RL, Anderson KA, Franzone JM, Kemp BE, Means AR, Witters LA (2005) The Ca2 +/calmodulin-dependent protein kinase kinases are AMP-activated protein kinase kinases. J Biol Chem 280: 29060-29066.

Inge LJ, Friel JM, Richer AL, Fowler AJ, Whitsett T, Smith MA, Tran NL, Bremner RM (2014) LKB1 inactivation sensitizes non-small cell lung cancer to pharmacological aggravation of ER stress. Cancer Lett 352: 187-195.

Inoki K, Zhu T, Guan KL (2003) TSC2 mediates cellular energy response to control cell growth and survival. Cell 115: 577-590.

Janus N, Thariat J, Boulanger H, Deray G, Launay-Vacher V (2010) Proposal for dosage adjustment and timing of chemotherapy in hemodialyzed patients. Ann Oncol 21: 1395-1403.

Ji H, Ramsey MR, Hayes DN, Fan C, McNamara K, Kozlowski P, Torrice C, Wu MC, Shimamura T, Perera SA, Liang MC, Cai D, Naumov GN, Bao L, Contreras CM, Li D, Chen L, Krishnamurthy J, Koivunen J, Chirieac LR, Padera RF, Bronson RT, Lindeman NI, Christiani DC, Lin X, Shapiro GI, Janne PA, Johnson BE, Meyerson M, Kwiatkowski DJ, Castrillon DH, Bardeesy N, Sharpless NE, Wong KK (2007) LKB1 modulates lung cancer differentiation and metastasis. Nature 448: 807-810.

Jishage K, Nezu J, Kawase Y, Iwata T, Watanabe M, Miyoshi A, Ose A, Habu K, Kake T, Kamada N, Ueda O, Kinoshita M, Jenne DE, Shimane M, Suzuki H (2002) Role of Lkb1, the causative gene of Peutz-Jegher's syndrome, in embryogenesis and polyposis. Proc Natl Acad Sci USA 99: 8903-8908.

Katajisto P, Vaahtomeri K, Ekman N, Ventela E, Ristimaki A, Bardeesy N, Feil R, DePinho RA, Makela TP (2008) LKB1 signaling in mesenchymal cells required for suppression of gastrointestinal polyposis. Nat Genet 40: 455-459.

Kaufman JM, Amann JM, Park K, Arasada RR, Li H, Shyr Y, Carbone DP (2014) LKB1 Loss induces characteristic patterns of gene expression in human tumors associated with NRF2 activation and attenuation of PI3K-AKT. J Thorac Oncol 9: 794-804.

Kim HS, Mendiratta S, Kim J, Pecot CV, Larsen JE, Zubovych I, Seo BY, Kim J, Eskiocak B, Chung H, McMillan E, Wu S, De Brabander J, Komurov K, Toombs JE, Wei S, Peyton M, Williams N, Gazdar AF, Posner BA, Brekken RA, Sood AK, Deberardinis RJ, Roth MG, Minna JD, White MA (2013) Systematic identification of molecular subtype-selective vulnerabilities in non-small-cell lung cancer. Cell 155: 552-566.

Kline ER, Muller S, Pan L, Tighiouart M, Chen ZG, Marcus AI (2011) Localization-specific LKB1 loss in head and neck squamous cell carcinoma metastasis. Head Neck 33: 1501-1512.

Kline ER, Shupe J, Gilbert-Ross M, Zhou W, Marcus AI (2013) LKB1 represses focal adhesion kinase (FAK) signaling via a FAK-LKB1 complex to regulate FAK site maturation and directional persistence. J Biol Chem 288: $17663-17674$.

Kuner R, Falth M, Pressinotti NC, Brase JC, Puig SB, Metzger J, Gade S, Schafer G, Bartsch G, Steiner E, Klocker H, Sultmann H (2013) The maternal embryonic leucine zipper kinase (MELK) is upregulated in highgrade prostate cancer. J Mol Med (Berl) 91: 237-248.

Kusakai G, Suzuki A, Ogura T, Miyamoto S, Ochiai A, Kaminishi M, Esumi H (2004) ARK5 expression in colorectal cancer and its implications for tumor progression. Am J Pathol 164: 987-995.

Lalau JD (2010) Lactic acidosis induced by metformin: incidence, management and prevention. Drug safety 33: 727-740.

Li X, Nadauld L, Ootani A, Corney DC, Pai RK, Gevaert O, Cantrell MA, Rack PG, Neal JT, Chan CW, Yeung T, Gong X, Yuan J, Wilhelmy J, Robine S, Attardi LD, Plevritis SK, Hung KE, Chen CZ, Ji HP, Kuo CJ (2014) Oncogenic transformation of diverse gastrointestinal tissues in primary organoid culture. Nat Med 20: 769-777.

Liang MC, Ma J, Chen L, Kozlowski P, Qin W, Li D, Goto J, Shimamura T, Hayes DN, Meyerson M, Kwiatkowski DJ, Wong KK (2010) TSC1 loss synergizes with KRAS activation in lung cancer development in the mouse and confers rapamycin sensitivity. Oncogene 29: 1588-1597.

Liu L, Ulbrich J, Muller J, Wustefeld T, Aeberhard L, Kress TR, Muthalagu N, Rycak L, Rudalska R, Moll R, Kempa S, Zender L, Eilers M, Murphy DJ (2012a) Deregulated MYC expression induces dependence upon AMPKrelated kinase 5. Nature 483: 608-612.

Liu W, Monahan KB, Pfefferle AD, Shimamura T, Sorrentino J, Chan KT, Roadcap DW, Ollila DW, Thomas NE, Castrillon DH, Miller CR, Perou CM, Wong KK, Bear JE, Sharpless NE (2012b) LKB1/STK11 inactivation leads to expansion of a prometastatic tumor subpopulation in melanoma. Cancer Cell 21: 751-764.

Liu Y, Marks K, Cowley GS, Carretero J, Liu Q, Nieland TJ, Xu C, Cohoon TJ, Gao P, Zhang Y, Chen Z, Altabef AB, Tchaicha JH, Wang X, Choe S, Driggers EM, Zhang J, Bailey ST, Sharpless NE, Hayes DN, Patel NM, Janne PA, Bardeesy N, Engelman JA, Manning BD, Shaw RJ, Asara JM, Scully R, Kimmelman A, Byers LA, Gibbons DL, Wistuba, Heymach JV, Kwiatkowski DJ, Kim WY, Kung AL, Gray NS, Root DE, Cantley LC, Wong KK (2013) Metabolic and functional genomic studies identify deoxythymidylate kinase as a target in LKB1-mutant lung cancer. Cancer Discov 3: 870-879.

Lu S, Niu N, Guo H, Tang J, Guo W, Liu Z, Shi L, Sun T, Zhou F, Li H, Zhang J, Zhang B (2013) ARK5 promotes glioma cell invasion, and its elevated expression is correlated with poor clinical outcome. Eur J Cancer 49: $752-763$.

Maira SM, Stauffer F, Brueggen J, Furet P, Schnell C, Fritsch C, Brachmann S, Chene P, De Pover A, Schoemaker K, Fabbro D, Gabriel D, Simonen M, Murphy L, Finan P, Sellers W, Garcia-Echeverria C (2008) Identification and characterization of NVP-BEZ235, a new orally available dual phosphatidylinositol 3-kinase/mammalian target of rapamycin inhibitor with potent in vivo antitumor activity. Mol Cancer Ther 7: 1851-1863.

Martin-Belmonte F, Perez-Moreno M (2012) Epithelial cell polarity, stem cells and cancer. Nat Rev Cancer 12: 23-38.

McCormack FX, Inoue Y, Moss J, Singer LG, Strange C, Nakata K, Barker AF, Chapman JT, Brantly ML, Stocks JM, Brown KK, Lynch 3rd JP, Goldberg HJ, Young LR, Kinder BW, Downey GP, Sullivan EJ, Colby TV, McKay RT, Cohen MM, Korbee L, Taveira-DaSilva AM, Lee HS, Krischer JP, Trapnell BC (2011) Efficacy and safety of sirolimus in lymphangioleiomyomatosis. N Engl J Med 364: 1595-1606.

Medina PP, Romero OA, Kohno T, Montuenga LM, Pio R, Yokota J, Sanchez-Cespedes M (2008) Frequent BRG1/SMARCA4-inactivating mutations in human lung cancer cell lines. Hum Mutat 29: 617-622.

Mihaylova MM, Shaw RJ (2011) The AMPK signalling pathway coordinates cell growth, autophagy and metabolism. Nat Cell Biol 13: 1016-1023.

Miyoshi H, Nakau M, Ishikawa TO, Seldin MF, Oshima M, Taketo MM (2002) Gastrointestinal hamartomatous polyposis in Lkb1 heterozygous knockout mice. Cancer Res 62: 2261-2266.

Mohseni M, Sun J, Lau A, Curtis S, Goldsmith J, Fox VL, Wei C, Frazier M, Samson O, Wong KK, Kim C, Camargo FD (2014) A genetic screen identifies an LKB1-MARK signalling axis controlling the Hippo-YAP pathway. Nat Cell Biol 16: 108-117.

Nakada D, Saunders TL, Morrison SJ (2010) Lkb1 regulates cell cycle and energy metabolism in haematopoietic stem cells. Nature 468: 653-658.

Nakada Y, Stewart TG, Pena CG, Zhang S, Zhao N, Bardeesy N, Sharpless NE, Wong KK, Hayes DN, Castrillon DH (2013) The LKB1 tumor suppressor as a biomarker in mouse and human tissues. PloS One 8: e73449.

Namiki T, Tanemura A, Valencia JC, Coelho SG, Passeron T, Kawaguchi M, Vieira WD, Ishikawa M, Nishijima W, Izumo T, Kaneko Y, Katayama I, Yamaguchi Y, Yin L, Polley EC, Liu H, Kawakami Y, Eishi Y, Takahashi E, Yokozeki H, Hearing VJ (2011) AMP kinase-related kinase NUAK2 affects tumor growth, migration, and clinical outcome of human melanoma. Proc Natl Acad Sci USA 108: 6597-6602.

Nardella C, Lunardi A, Patnaik A, Cantley LC, Pandolfi PP (2011) The APL paradigm and the 'co-clinical trial' project. Cancer Discov 1: 108-116.

O’Reilly KE, Rojo F, She QB, Solit D, Mills GB, Smith D, Lane H, Hofmann F, Hicklin DJ, Ludwig DL, Baselga J, Rosen N (2006) mTOR inhibition induces upstream receptor tyrosine kinase signaling and activates Akt. Cancer Res 66: 1500-1508.

Oakhill JS, Steel R, Chen ZP, Scott JW, Ling N, Tam S, Kemp BE (2011) AMPK is a direct adenylate charge-regulated protein kinase. Science 332: 1433-1435.

Ohara G, Miyazaki K, Kurishima K, Kagohashi K, Ishikawa H, Satoh H, Hizawa N (2012) Safety creatinine clearance level for platinum chemotherapy in lung cancer patients. Oncol Lett 3: 311-314. 
Ollila S, Makela TP (2011) The tumor suppressor kinase LKB1: lessons from mouse models. J Mol Cell Biol 3: 330-340.

Osoegawa A, Kometani T, Nosaki K, Ondo K, Hamatake M, Hirai F, Seto T, Sugio K, Ichinose Y (2011) LKB1 mutations frequently detected in mucinous bronchioloalveolar carcinoma. Jpn J Clin Oncol 41: 1132-1137.

Ostrem JM, Peters U, Sos ML, Wells JA, Shokat KM (2013) K-Ras(G12C) inhibitors allosterically control GTP affinity and effector interactions. Nature 503: 548-551.

Owen MR, Doran E, Halestrap AP (2000) Evidence that metformin exerts its anti-diabetic effects through inhibition of complex 1 of the mitochondrial respiratory chain. Biochem J 348: 607-614.

Pickard MR, Green AR, Ellis IO, Caldas C, Hedge VL, Mourtada-Maarabouni M, Williams GT (2009) Dysregulated expression of Fau and MELK is associated with poor prognosis in breast cancer. Breast Cancer Res 11: R60.

Pineda CT, Ramanathan S, Fon Tacer K, Weon JL, Potts MB, Ou YH, White MA, Potts PR (2015) Degradation of AMPK by a cancer-specific ubiquitin ligase. Cell 160: 715-728.

Pollak M (2010) Metformin and other biguanides in oncology: advancing the research agenda. Cancer Prev Res (Phila) 3: 1060-1065.

Qi WX, Tang LN, He AN, Yao Y, Shen Z (2013) Incidence and risk of treatment-related mortality in cancer patients treated with EGFR-TKIs: a meta-analysis of 22 phase III randomized controlled trials. Respir Med 107: $1280-1283$.

Rines AK, Burke MA, Fernandez RP, Volpert OV, Ardehali H (2012) Snf1-related kinase inhibits colon cancer cell proliferation through calcyclin-binding protein-dependent reduction of beta-catenin. FASEB $J$ 26: $4685-4695$.

Rodrik-Outmezguine VS, Chandarlapaty S, Pagano NC, Poulikakos PI, Scaltriti M, Moskatel E, Baselga J, Guichard S, Rosen N (2011) mTOR kinase inhibition causes feedback-dependent biphasic regulation of AKT signaling. Cancer Discov 1: 248-259.

Roh SA, Choi EY, Cho DH, Jang SJ, Kim SY, Kim YS, Kim JC (2010) Growth and invasion of sporadic colorectal adenocarcinomas in terms of genetic change. J Korean Med Sci 25: 353-360.

Rossi DJ, Ylikorkala A, Korsisaari N, Salovaara R, Luukko K, Launonen V, Henkemeyer M, Ristimaki A, Aaltonen LA, Makela TP (2002) Induction of cyclooxygenase-2 in a mouse model of Peutz-Jeghers polyposis. Proc Natl Acad Sci USA 99: 12327-12332.

Sanchez-Cespedes M (2007) A role for LKB1 gene in human cancer beyond the Peutz-Jeghers syndrome. Oncogene 26: 7825-7832.

Sanchez-Cespedes M, Parrella P, Esteller M, Nomoto S, Trink B, Engles JM, Westra WH, Herman JG, Sidransky D (2002) Inactivation of LKB1/STK11 is a common event in adenocarcinomas of the lung. Cancer Res 62: 3659-3662.

Schneider MB, Matsuzaki H, Haorah J, Ulrich A, Standop J, Ding XZ, Adrian TE, Pour PM (2001) Prevention of pancreatic cancer induction in hamsters by metformin. Gastroenterology 120: 1263-1270.

Segal ED, Yasmeen A, Beauchamp MC, Rosenblatt J, Pollak M, Gotlieb WH (2011) Relevance of the OCT1 transporter to the antineoplastic effect of biguanides. Biochem Biophys Res Commun 414: 694-699.

Selvik LK, Rao S, Steigedal TS, Haltbakk I, Misund K, Bruland T, Prestvik WS, Laegreid A, Thommesen L (2014) Salt-inducible kinase 1 (SIK1) is induced by gastrin and inhibits migration of gastric adenocarcinoma cells. PLoS One 9: e112485.

Shackelford DB (2013) Unravelling the connection between metabolism and tumorigenesis through studies of the liver kinase B1 tumour suppressor. J Carcinog 12: 16.

Shackelford DB, Abt E, Gerken L, Vasquez DS, Seki A, Leblanc M, Wei L, Fishbein MC, Czernin J, Mischel PS, Shaw RJ (2013a) LKB1 inactivation dictates therapeutic response of non-small cell lung cancer to the metabolism drug phenformin. Cancer Cell 23: 143-158.

Shackelford DB, Abt E, Gerken L, Vasquez DS, Seki A, Leblanc M, Wei L, Fishbein MC, Czernin J, Mischel PS, Shaw RJ (2013b) LKB1 inactivation dictates therapeutic response of non-small cell lung cancer to the metabolism drug phenformin. Cancer Cell 23(2): 143-158.

Shackelford DB, Shaw RJ (2009) The LKB1-AMPK pathway: metabolism and growth control in tumour suppression. Nat Rev Cancer 9: 563-575.

Shackelford DB, Vasquez DS, Corbeil J, Wu S, Leblanc M, Wu CL, Vera DR, Shaw RJ (2009a) mTOR and HIF-lalpha-mediated tumor metabolism in an LKB1 mouse model of Peutz-Jeghers syndrome. Proc Natl Acad Sci USA 106: 11137-11142.

Shackelford DB, Vasquez DS, Corbiel J, Wu S, Leblanc M, Wu CL, Vera DR, Shaw RJ (2009b) mTOR-dependent regulation of polyposis and HIF- $1 \alpha$ mediated glucose metabolism in an LKB1 mouse model of Peutz-Jeghers syndrome. Proc Natl Acad Sci USA. in press 106: 11137-11142.

Shaw RJ, Bardeesy N, Manning BD, Lopez L, Kosmatka M, DePinho RA, Cantley LC (2004a) The LKB1 tumor suppressor negatively regulates mTOR signaling. Cancer Cell 6: 91-99.

Shaw RJ, Kosmatka M, Bardeesy N, Hurley RL, Witters LA, DePinho RA, Cantley LC (2004b) The tumor suppressor LKB1 kinase directly activates AMP-activated kinase and regulates apoptosis in response to energy stress. Proc Natl Acad Sci USA 101: 3329-3335.

Shorning BY, Griffiths D, Clarke AR (2011) Lkbl and Pten synergise to suppress mTOR-mediated tumorigenesis and epithelial-mesenchymal transition in the mouse bladder. PloS One 6: e16209.

Strohecker AM, Guo JY, Karsli-Uzunbas G, Price SM, Chen GJ, Mathew R, McMahon M, White E (2013) Autophagy sustains mitochondrial glutamine metabolism and growth of BrafV600E-driven lung tumors. Cancer Discov 3: 1272-1285.

Suzuki A, Iida S, Kato-Uranishi M, Tajima E, Zhan F, Hanamura I, Huang Y, Ogura T, Takahashi S, Ueda R, Barlogie B, Shaughnessy Jr J, Esumi H (2005) ARK5 is transcriptionally regulated by the large-MAF family and mediates IGF-1-induced cell invasion in multiple myeloma: ARK5 as a new molecular determinant of malignant multiple myeloma. Oncogene 24: 6936-6944.

Suzuki A, Lu J, Kusakai G, Kishimoto A, Ogura T, Esumi H (2004) ARK5 is a tumor invasion-associated factor downstream of Akt signaling. Mol Cell Biol 24: 3526-3535.

Tanwar PS, Kaneko-Tarui T, Zhang L, Tanaka Y, Crum CP, Teixeira JM (2012) Stromal liver kinase B1 [STK11] signaling loss induces oviductal adenomas and endometrial cancer by activating mammalian target of rapamycin complex 1. PLoS Genet 8: e1002906.

Topalian SL, Hodi FS, Brahmer JR, Gettinger SN, Smith DC, McDermott DF, Powderly JD, Carvajal RD, Sosman JA, Atkins MB, Leming PD, Spigel DR, Antonia SJ, Horn L, Drake CG, Pardoll DM, Chen L, Sharfman WH, Anders RA, Taube JM, McMiller TL, Xu H, Korman AJ, Jure-Kunkel M, Agrawal S, McDonald D, Kollia GD, Gupta A, Wigginton JM, Sznol M (2012) Safety, activity, and immune correlates of anti-PD-1 antibody in cancer. $N$ Engl J Med 366: 2443-2454.

Wander SA, Hennessy BT, Slingerland JM (2011) Next-generation mTOR inhibitors in clinical oncology: how pathway complexity informs therapeutic strategy. J Clin Invest 121: 1231-1241.

Wang H, Liu XB, Chen JH, Wang QQ, Chen JP, Xu JF, Sheng CY, Ni QC (2014) Decreased expression and prognostic role of cytoplasmic BRSK1 in human breast carcinoma: correlation with Jab1 stability and PI3K/Akt pathway. Exp Mol Pathol 97: 191-201.

Wei C, Amos CI, Zhang N, Wang X, Rashid A, Walker CL, Behringer RR, Frazier ML (2008) Suppression of Peutz-Jeghers polyposis by targeting mammalian target of rapamycin signaling. Clin Cancer Res 14: 1167-1171.

Wilkerson MD, Yin X, Walter V, Zhao N, Cabanski CR, Hayward MC, Miller CR, Socinski MA, Parsons AM, Thorne LB, Haithcock BE, Veeramachaneni NK, Funkhouser WK, Randell SH, Bernard PS, Perou CM, Hayes DN (2012) Differential pathogenesis of lung adenocarcinoma subtypes involving sequence mutations, copy number, chromosomal instability, and methylation. PloS One 7: e36530.

Wingo SN, Gallardo TD, Akbay EA, Liang MC, Contreras CM, Boren T, Shimamura T, Miller DS, Sharpless NE, Bardeesy N, Kwiatkowski DJ, Schorge JO, Wong KK, Castrillon DH (2009) Somatic LKB1 mutations promote cervical cancer progression. PLoS One 4: e5137.

Woods A, Dickerson K, Heath R, Hong SP, Momcilovic M, Johnstone SR, Carlson M, Carling D (2005) C(Ca2+)/calmodulin-dependent protein kinase kinase-beta acts upstream of AMP-activated protein kinase in mammalian cells. Cell Metab 2: 21-33.

Woods A, Johnstone SR, Dickerson K, Leiper FC, Fryer LG, Neumann D, Schlattner U, Wallimann T, Carlson M, Carling D (2003) LKB1 is the upstream kinase in the AMP-activated protein kinase cascade. Curr Biol 13: 2004-2008.

Xiao B, Sanders MJ, Underwood E, Heath R, Mayer FV, Carmena D, Jing C, Walker PA, Eccleston JF, Haire LF, Saiu P, Howell SA, Aasland R, Martin SR, Carling D, Gamblin SJ (2011) Structure of mammalian AMPK and its regulation by ADP. Nature 472: 230-233.

Xu C, Fillmore CM, Koyama S, Wu H, Zhao Y, Chen Z, Herter-Sprie GS, Akbay EA, Tchaicha JH, Altabef A, Reibel JB, Walton Z, Ji H, Watanabe H, Janne PA, Castrillon DH, Rustgi AK, Bass AJ, Freeman GJ, Padera RF, Dranoff G, Hammerman PS, Kim CF, Wong KK (2014) 
Loss of Lkb1 and Pten leads to lung squamous cell carcinoma with elevated PD-L1 expression. Cancer Cell 25: 590-604.

Ylikorkala A, Rossi DJ, Korsisaari N, Luukko K, Alitalo K, Henkemeyer M, Makela TP (2001) Vascular abnormalities and deregulation of VEGF in Lkb1-deficient mice. Science 293: 1323-1326.

Zhang WC, Shyh-Chang N, Yang H, Rai A, Umashankar S, Ma S, Soh BS, Sun LL, Tai BC, Nga ME, Bhakoo KK, Jayapal SR, Nichane M, Yu Q, Ahmed DA, Tan C, Sing WP, Tam J, Thirugananam A, Noghabi MS, Pang YH, Ang HS, Mitchell W, Robson P, Kaldis P, Soo RA, Swarup S, Lim EH, Lim B (2012) Glycine decarboxylase activity drives non-small cell lung cancer tumor-initiating cells and tumorigenesis. Cell 148: 259-272.

Zheng B, Jeong JH, Asara JM, Yuan YY, Granter SR, Chin L, Cantley LC (2009) Oncogenic B-RAF negatively regulates the tumor suppressor LKB1 to promote melanoma cell proliferation. Mol Cell 33: 237-247.
(c) (i)
This work is licensed under the Creative License. To view a copy of this license, visit http://creativecom- mons.org/licenses/by/4.0/ 